\title{
An exploration on e-retailers' home delivery - strategic elements and their prioritisation
}

\author{
Chengbo Wang ${ }^{1}$, Zhaofang Mao ${ }^{2}$, James O'Kane ${ }^{1}$, and Jun Wang ${ }^{3}$ \\ 1. Edge Hill University, Ormskirk, UK. Email: chengbo.wang@edgehill.ac.uk \\ 2. Tianjin University, Tianjin, China \\ 3. Zhejiang Gongshang University, Hangzhou, China
}

\begin{abstract}
This paper introduces a research exploring the important strategic elements and their prioritisation for e-retailers' home delivery supply's efficacy improvement.

The research was completed through literature review, focus group, survey and importanceperformance analysis (IPA). It identified, confirmed and prioritised a set of explicitly important strategic elements currently deemed important by e-retailers for ensuring the efficacy of their home delivery logistics processes in Chinese marketplace. The findings contribute to the enrichment of the theoretical knowledge pool of e-retailers' logistics performance improvement, and guide/inform the strategy development and implementation for e-retailers entering and/or operating in Chinese and other similar emerging marketplaces.
\end{abstract}

Key words: E-retail, Strategy, Home delivery, Importance-performance analysis (IPA), Prioritisation, China

\section{Introduction}

Evidenced by the continuously increased e-retailing sales (Chang, et al., 2013; Clark, 2011; Lockwood, 2013), China with its vast online shopping consumer population (CERC, 2012; Zhang and Zhang, 2012), is a very profitable marketplace for e-retailers (Lockwood, 2013). Naturally, it is not a surprise that there are many foreign and Chinese e-retailers entering and operating in the market. Compared with their counterparts in the developed countries such as the UK, the e-retail businesses in China started later, but are performing well and growing rapidly (Chang, et al., 2013; Clark, 2011; Liu, 2012).

However although the Chinese retail sector is booming, very often the foreign e-retailers in China while following the strategies implemented in their home countries, are less competitive than their Chinese local peers (Wang and Ren, 2012; Liu, 2012); this phenomenon is evidenced by some of them failing in obtaining or maintaining sufficient market share/profit and withdrawing from the Chinese e-commerce marketplace fully or partially (CYONE, 2013; Liu, 2012). This raises the question on whether the e-retail strategies implemented in these foreign e-retailers' home countries are still effective in Chinese marketplace. Therefore it is necessary to study on what of those retailing strategic elements implemented in foreign marketplaces are regarded as important by Chinese e-retailers, as well as their importance level and prioritisation, to inform foreign and local e-retailers in developing competitive strategies. Meanwhile, evidenced by research, among the strategies ensuring e-retailers' business success, the home delivery strategic elements are very crucial (Starkey, 2010; Benady, 2013; comScore, 2012; Spijkerman, 2008; Sebastianelli and Tamimi, 2013; Rutter and Southerton, 2000), 
reflected by their heavy impacts on customer satisfaction and retention (Starkey, 2010) in any country with e-retailing existence, especially such as in China - a rapidly developing market (Chang, et al., 2013; Liu, 2012). Corresponding to such a phenomenon, and resonated by the contention from researchers, further research is much needed on e-retailing home delivery performance management (Park and Regan, 2004; Grewal and Levy, 2009; comScore, 2012; Galpin, 2013; JLL, 2013).

Thus in this research the authors intend to address such a question: what are the important strategic elements and their prioritisation for ensuring and improving e-retailers' home delivery efficacy. Namely the following issues will be investigated:

1) The currently implemented home delivery strategic elements in the UK and other developed countries, and

2) The importance level/performance level of these elements from the dimension of Chinese eretailers to their business success, which consequentially lead to the prioritisation of these elements, informing the e-retailers' strategy development.

Besides guiding the e-retailers' home delivery strategies in Chinese marketplace, the findings can also inform the strategy development for entering/operating in other emerging ones, since that the e-retailing in the other emerging markets share similar business model and growth rate as that of China (Chang, et al., 2013). This research ultimately contributes to both theory development and practical guidance provision in e-retailing logistics service performance enhancement.

\section{Literature review}

2.1 E-retailers' home delivery performance and its importance

E-retailing refers to selling goods/services through internet, including business activities between business-to-business (B2B) and business-to-customer (B2C); e-retailers can be online only or multichannel business (Rose, et al., 2012; Grewal and Levy, 2009; Liao, et al., 2011).

In recent decades, e-retailing is becoming an indispensable part of retail industry (Grewal and Levy, 2009; Ganesan et al., 2009; CERC, 2012, 2014; Karakaya, 2001; Zhang and Zhang, 2012; Spijkerman, 2008; Stokes and Jensen, 2011; Abdul-Muhmin, 2010) and growing at a rapid pace (Stokes and Jensen 2011; Park and Regan, 2004; Clark, 2011; Liu, 2012). With the relative ease of managing on-line business transactions and other relevant activities, the number of e-retailers increases dramatically; and the amount of consumers purchasing from echannels has also increased rapidly (Rao, et al., 2011; Chang, et al., 2013; Li and Dinlersoz, 2012). To ensure a satisfactory purchase experience to customers and the popularity of ecommerce, the efficacy of home delivery or "last mile" plays a critical role (Punakivi, et al., 2001; Park and Regan, 2004; Lee and Whang, 2001; Li and Dinlersoz, 2012; Goethals, et al., 2011). And research has confirmed and emphasized the vital importance of home delivery to ecommerce success (Li and Dinlersoz, 2012; Gil-Saura, et al., 2010; Goethals, et al., 2011).

Under the retail e-commerce context, herein this paper, home delivery refers to e-retailers through their own logistics service function and/or a third party logistics service provider to deliver ordered goods to a location per the customers' preference (Asdemir, et al., 2009; Punakivi and Saranen, 2001; Rutter and Southerton, 2000). The e-retailers focused by this research are those online only "pure players" (Rose, et al., 2012); and "home" herein refers to any place where customers want their ordered items to be delivered to. 
Home delivery service is a critical part of the customer's online purchase cycle (de Koster, 2003; Rao, et al., 2011). An e-retailer's home delivery performance can decisively impact its customers' loyalty and their perception of its corporate image.

Currently although the customers benefit from e-retailing service, they still often have complaints on e-retailers' performance; one of the key aspect focused by the complaints is the home delivery system (Starkey, 2010; Benady, 2013); this phenomenon is seen in different countries/regions, such as the customers' increased unsatisfaction on e-retailers' delivery service during holiday seasons in the UK (Kaffash, 2012; Jopson, 2013).

The e-retailers' home delivery performance has in recent years aroused much attention from researchers and practical professionals (Rao, et al., 2011; Li and Dinlersoz, 2012; Goethals, et al., 2011), however compared to the research on other aspects of e-retailing, the published literature focusing on home delivery strategic elements and their implementation to ensure eretailing efficiency and effectiveness is rather scarce; and the importance and need of further research on this perspective has been emphasised by many researchers and practical professionals (Park and Regan, 2004; Grewal and Levy, 2009; comScore, 2012; Galpin, 2013; JLL, 2013). Particularly, among the extant research, vast majority of them focus on the eretailers in the developed countries; thus the research with a focus on Chinese e-retail marketplace will be very informative for exploring and operating in China and other developing marketplaces, following the contention from Chang, et al. (2013) that the e-retailing in emerging markets share similar business model and growth rate.

\subsection{Strategic dimensions and elements of home delivery operations}

Based on the literature review and further verification and enrichment through the consensual viewpoints from a focus group with five experts in the e-retail businesses and the further consolidation by the authors, the main strategic dimensions applied in e-retailing home delivery operations and the identified strategic elements implemented by developed countries' eretailers under each dimension are summarised in Table 1.

Table 1. Dimensions and corresponding component strategic elements (and their codes) for eretailing home delivery operations

\begin{tabular}{|c|c|c|c|}
\hline Dimension & Delivery time arrangement (DTA) & DTA & $\begin{array}{l}\text { Sources (literature: direct } \\
\text { and/or inspired from; focus } \\
\text { group consensual viewpoints) }\end{array}$ \\
\hline \multirow{5}{*}{$\begin{array}{l}\text { Strategic } \\
\text { elements }\end{array}$} & Same day delivery & DTA_1 & \multirow{5}{*}{$\begin{array}{l}\text { MICROS, 2012; Starkey, 2010; } \\
\text { Forbes, et al., 2005; Greasley } \\
\text { and Assi, 2012; Benady, 2013; } \\
\text { Spijkerman, 2008; Jopson, } \\
\text { 2013; Teller, Kotzab and Grant, } \\
\text { 2006; Abdul-Muhmin, 2010; Li } \\
\text { and Dinlersoz, 2012; Liao, et al., } \\
2011\end{array}$} \\
\hline & Two-day delivery & DTA_2 & \\
\hline & Weekend delivery & DTA_3 & \\
\hline & Delivery by customer appointed date & DTA_4 & \\
\hline & Delivery by customer appointed date and time & DTA_5 & \\
\hline \multirow[t]{2}{*}{ Dimension } & Flexibility of the delivery arrangement (FDA) & FDA & $\begin{array}{l}\text { Sources (literature: direct } \\
\text { and/or inspired from; focus } \\
\text { group consensual viewpoints) }\end{array}$ \\
\hline & Can only deliver in the time slot decided by retailer & FDA_1 & $\begin{array}{l}\text { Starkey, 2010: MICROS, 2012; } \\
\text { Forbes, et al., 2005; Greasley }\end{array}$ \\
\hline
\end{tabular}




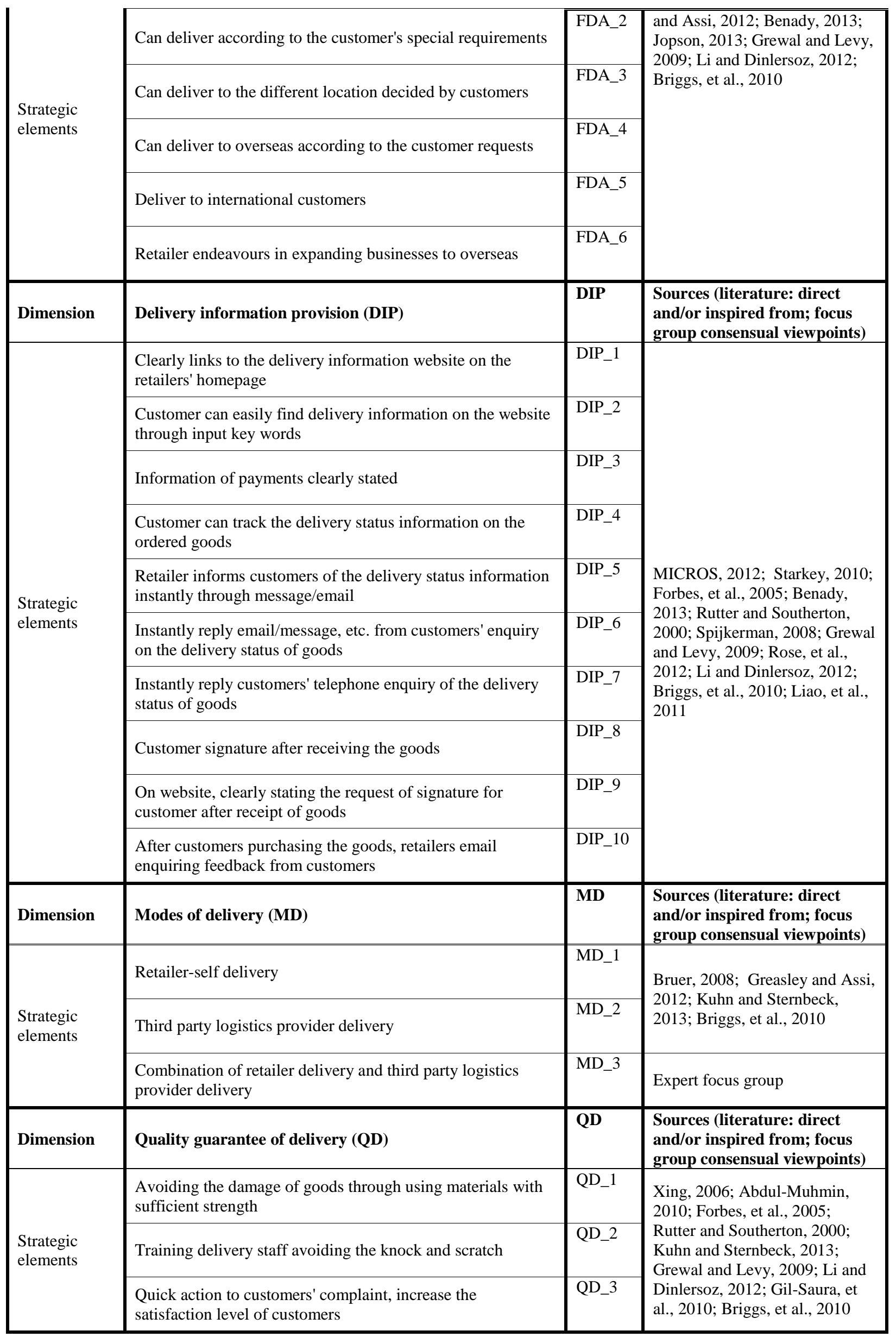




\begin{tabular}{|l|l|l|l|}
\hline \multirow{2}{*}{ Dimension } & Quality of the delivery staff's work (QSW) & QSW & $\begin{array}{l}\text { Sources (literature: direct } \\
\text { and/or inspired from; focus } \\
\text { group consensual viewpoints) }\end{array}$ \\
\hline \multirow{2}{*}{$\begin{array}{l}\text { Strategic } \\
\text { elements }\end{array}$} & Recruiting high quality staff & QSW_1 & Expert focus group \\
\cline { 2 - 4 } & Regular training before and after the staff assuming posts & QSW_2 & Expert focus group \\
\hline
\end{tabular}

Nevertheless, these dimensions and their corresponding component strategic elements were identified/developed based on the e-retailing conditions mainly in developed countries. How important/prioritised they are to local e-retailers in developing countries remain interesting issues.

As one of the fast developing countries, China has a huge marketplace (CERC, 2012; Zhang and Zhang, 2012) that deserves further exploration from businesses including local and international e-retailers. There are already international e-retailers operating in the Chinese marketplace, but many of them were not as successful as hoped, through following the strategies that have been implemented in their home countries (Wang and Ren, 2012; Liu, 2012). Therefore, a study to check the applicability of the aforementioned strategic elements under a Chinese context will provide significant contribution to both the theoretical knowledge pool enrichment and the practical guidance provision for e-retailers' home delivery operations.

\section{Research methodology}

\subsection{General research approach}

The concrete research strategy contains five steps, as depicted in Figure 1.

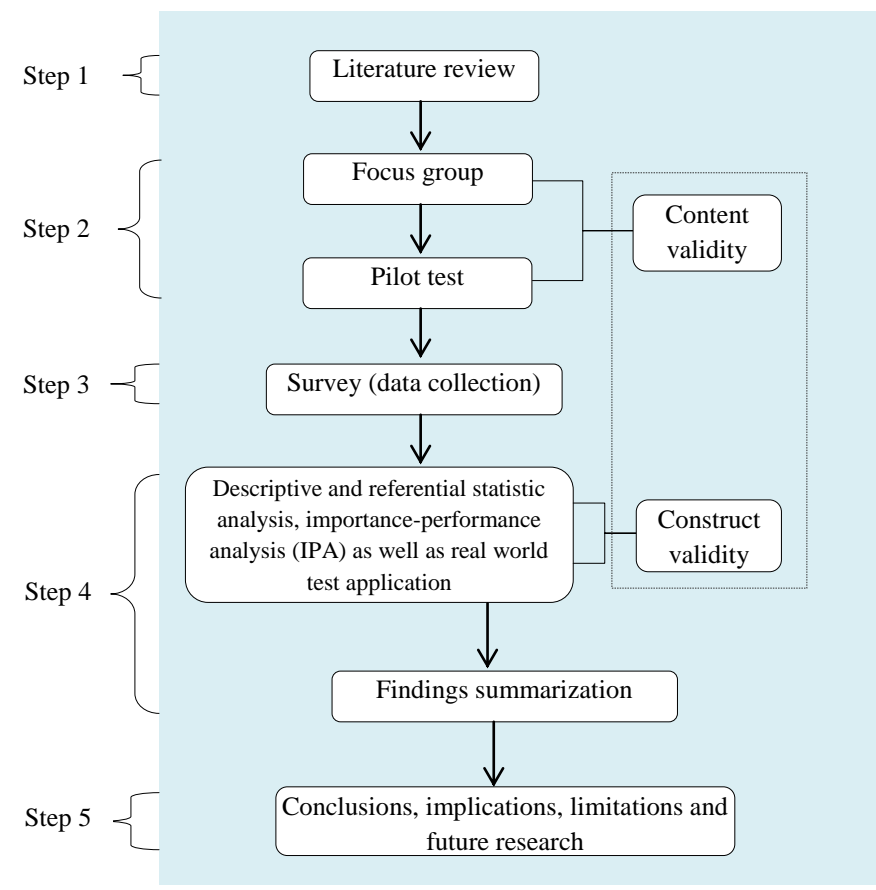

Figure 1. Diagrammatic depiction of general research strategy

The details of each step are as following: 
Step 1, the authors conducted a literature review focusing on British and other developed countries' e-retailers' home delivery strategies, which have been applied to ensure, maintain and improve the home delivery performance. From the literature review, the dimensions/strategic elements for e-retailers' home delivery operations were primarily identified and developed.

Step 2, based on the findings from the previous step, the dimensions/strategic elements (Table 1) for e-retailers' home delivery operations were triangulated, enriched through the focus group of experts in e-retail field based on their professional knowledge; the content validity was examined at this step; and the survey questionnaire containing the same items as in Table 1 was developed and pilot tested.

Step 3, the survey was carried out through researcher administered format, by asking respondents to rate the importance level and the performance level of the respective strategic elements (performance level refers to the implementation status - the realisation level of the intended results through implementing the aforementioned strategic elements on their focused business aspects).

Step 4, the research findings were summarised, based on statistic analysis and importanceperformance analysis (IPA) for the most important strategic elements' determination and prioritisation for guiding their practical application, as well as the real world test application of the prioritised strategic elements. Construct validity was also checked at this step.

Step 5, conclusions, implications, limitations and future research were presented.

\subsection{Brief introduction of the methods employed by the research}

3.2.1 Focus group technique

Focus group technique is a popular research method through summiting a group of experts with substantial knowledge/experience in a research focused field for discussion and consequentially provision of insights and opinions on certain issues (Evason and Whittington, 1997).

A focus group session can have four to twelve participants (Krueger, 1994; Crowley and Gilreath, 2002). A smaller sized focus group can provide easy control of discussion/ communication without losing crucial information (Krueger, 1994). Following this contention, this research selected five managers having been working in the e-retail fields for six to ten years respectively to form a focus group to evaluate the literature identified e-retailing strategic elements and to enrich the literature findings through their empirical experience.

The focus group participants were required to evaluate the appropriateness of the strategic elements following a five-point Likert scale (1932) (Very appropriate - 5 to Very inappropriate - 1), and to propose additional elements deemed necessary. Meanwhile, besides the confirmed and further identified/proposed strategic elements, the usefulness of the project is also to be verified by the experts, as well as the necessity to prioritise the strategic elements and determination of the demarcation lines for separating importance and performance levels for analysis.

\subsubsection{Survey}

Survey is a very effective research instrument for obtaining factual information of opinions and attitudes from respondents; and it is frequently used for research in retail and logistics fields (e.g., de Koster, 2003; Starkey, 2010; Abdul-Muhmin, 2011).

The survey respondents in this research were required to evaluate the strategic elements' importance and performance levels; the importance level/performance level are rated following 
a five-point scale [5 - Highly important/Very well implemented (having achieved all of the intended results), 4 - Important/Well implemented (having achieved majority of the intended results), 3 - Slightly important/Partially implemented (having achieved some of the intended results), 2 - Nearly not important/Limitedly implemented (having achieved very little of the intended results), 1 - Definitely not important/Non implemented (having achieved nothing of the intended results)].

\subsubsection{Importance-Performance Analysis (IPA) for prioritisation}

Importance-Performance Analysis (IPA) (Martilla and James, 1977) is a technique that can be used to identify strengths and weaknesses of business processes/activities by comparing the recognition on the importance of the attributes and evaluation of the performance level in terms of these attributes (Wang, et al, 2011-12), herein referring to the importance and performance levels of the e-retailing home delivery operations strategic elements. Through IPA, a business can have in-depth insights and a clearer understanding of what elements should be allocated more effort and resources for improving customer satisfaction and business performance.

\subsection{Selection of the sample respondents}

The data collection was conducted through surveying e-retailers purposively recommended by the focus group field experts. This sample selection strategy of expert recommendation is decided corresponding to the situation that currently there are many e-retailers emerging into marketplace however with short life span of survival (Liu and Xu, 2010; TopCapital, 2013); a sample group selected through a strict expert screening can ensure its members' validity for providing substantial insights for the research.

Selection criteria of the sample e-retailers are: the e-retailers 1) must have been in business more than 5 years; 2) must be in profitable financial status; 3 ) their businesses have national coverage and wide notability and popularity.

From the e-retailers (DMOZlist, 2012; 51ZJXM, 2011a,b) in the regions with representative high level of e-commerce application (CMIC, 2012; EEO, 2010), 89 business active e-retailers were selected for primary contact, which helps in increasing the response; and finally 33 of them provided completed answers to the questionnaire, producing a response rate of $37.1 \%$; among these respondents there are 14 large sized, 8 medium sized and 11 small sized eretailers, following the classification of the enterprise size from European Commission (2005) and Sadi and Iftikhar (2011). Evidenced by the T-test scores (Table 6) on the collected data, the 33 samples can be treated as a whole for analysis of research findings.

As an exploratory research, based on the aforementioned attributes of the sample e-retailers, the findings from them can provide constructive information for the whole sector.

\subsection{Validity and reliability of the research}

3.4.1 Validity of the research

\subsubsection{Content validity}

The questionnaire content was developed based on the identified popular strategic elements for home delivery operations implemented by e-retailers in developed countries from the publicly available literatures; and then the questions (the strategic elements) were verified through the evaluation by the focus group containing the field experts, which include five operations/general managers in e-retailing sector. Through this screening and enrichment on the questions by experts, the content validity of the research instrument has been ensured ( $\mathrm{Yu}$, 2012; Kimberlin and Winterstein, 2008). The final evaluation result of the appropriateness of 
the questions is very positive with average ratings of 4 or above for all of them following the aforementioned five-point scale. The experts also firmly recognised the significant meaningfulness of the research project.

After the content validation, a pilot test with 5 e-retailers was conducted to further ensure the questionnaire's clarity and coverage. After a minor refinement (further approved by the focus group experts) based on the feedback information on a few questions' wording (the only issue identified from the pilot test), the questionnaire was distributed for real world data collection from the sample retailers.

\subsubsection{Construct validity}

Based on the collected data, a factor analysis was applied to check the construct validity, which is crucial and "ordinarily" tested for ensuring the validity of a research (Cronbach and Meehl, 1955; Westen and Rosenthal, 2003). As contended by researchers, factor analysis is a popular way to examine the construct validity of an instrument (Yu, 2012; Kimberlin and Winterstein, 2008).

Construct validity has two key elements: convergent validity and discriminant validity.

In this research, through factor analysis, the communality values and loadings of the elements to factors (respective strategic dimensions from the researchers' primary anticipation in Table 1) are summarised in Table 2 and Table 3. The communality values in Table 2 demonstrate that the investigation questions are appropriate (van Beuningen, 2012; Statwiki, 2012), except for MD_1, FDA_1 and FDA_2 with communality values of $0.18,0.42$ and 0.46 respectively (underlined in the table); while MD_1 will be dropped from the elements list together with a few others at later stage due to low importance ratings; the other two although with a little lower communality values, which are still above Pastor's (2013) threshold value and with their importance scores as further proof, they were kept in the list. In view of that the elements' loadings to the factors well above the threshold (Paswan, 2009; Pastor, 2013) and without additionally ramified factors, the sufficiency of small sample size for the validity is endorsed (Preacher and MacCallum, 2002; MacCallum, Widaman, Zhang and Hong, 1999; Costello and Osborne, 2005). Meanwhile evidenced by the significant factor loadings, the convergent validity has been primarily attested following Cole's contention (1987).

To further exam the convergent validity, average variance extracted (AVE) and construct reliability (CR) have also been calculated (Table 4). The results in Table 3 and 4, with strong factor loadings, the AVE values all above 0.5 and CR values all above 0.7 except 0.68 for MD, which can be compensated because of other indicators of the construct validity are good (Paswan, 2009), attested the convergent validity of the research.

Table 2. Strategic elements (survey questionnaire's content) with corresponding communality values

\begin{tabular}{|l|c|l|c|}
\hline Strategic element & Communality value & Strategic element & Communality value \\
\hline DTA_1 & 0.52 & DIP_5 & 0.73 \\
\hline DTA_2 & 0.81 & DIP_6 & 0.72 \\
\hline DTA_3 & 0.61 & DIP_7 & 0.52 \\
\hline DTA_4 & 0.88 & DIP_8 & 0.50 \\
\hline DTA_5 & 0.84 & DIP_9 & 0.97 \\
\hline FDA_1 & $\underline{0.42}$ & DIP_10 & 0.94 \\
\hline FDA_2 & $\underline{0.46}$ & $\underline{\text { MD_1 }}$ & $\underline{0.18}$ \\
\hline
\end{tabular}




\begin{tabular}{|l|l|l|l|}
\hline FDA_3 & 0.96 & MD_2 & 0.78 \\
\hline FDA_4 & 0.84 & MD_3 & 0.65 \\
\hline FDA_5 & 0.79 & QD_1 & 0.53 \\
\hline FDA_6 & 0.64 & QD_2 & 0.76 \\
\hline DIP_1 & 0.86 & QD_3 & 0.83 \\
\hline DIP_2 & 0.88 & QSW_1 & 0.97 \\
\hline DIP_3 & 0.86 & QSW_2 & 0.51 \\
\hline DIP_4 & 0.92 & & \\
\hline
\end{tabular}

Table 3. Loadings of components (Strategic elements) to factors

\begin{tabular}{|l|c|}
\hline Factors (Dimensions of home delivery strategy) & $\begin{array}{l}\text { Range of the components' (Strategic } \\
\text { elements) loadings (to Factors) }\end{array}$ \\
\hline Delivery time arrangement (DTA) & $0.72 \sim 0.92$ \\
\hline Flexibility of the delivery arrangement (FDA) & $0.8 \sim 0.98$ \\
\hline Delivery information provision (DIP) & $0.71 \sim 0.98$ \\
\hline Modes of delivery (MD) & $0.81 \sim 0.88$ \\
\hline Quality guarantee of delivery (QD) & $0.73 \sim 0.91$ \\
\hline Quality of the delivery staff's work (QSW) & $0.71 \sim 0.98$ \\
\hline
\end{tabular}

To examine the discriminant validity, one needs to compare average variance extracted (AVE) with the corresponding squared interconstruct correlation estimates (SIC); and AVE should be larger than SIC to ensure a discriminant validity (Paswan, 2009). Table 4 contains the AVE and SIC values corresponding to the constructs (dimensions of home delivery strategy and their elements).

Table 4. AVE, CR values and SIC values' range

\begin{tabular}{|l|l|l|l|l|l|l|}
\hline \multicolumn{1}{|r|}{ Construct } & DTA & FDA & DIP & MD & QD & QSW \\
\hline Value/Value range & 0.56 & 0.67 & 0.65 & 0.52 & 0.52 & 0.60 \\
\hline Average Variance Extracted (AVE) & 0.86 & 0.89 & 0.95 & 0.68 & 0.76 & 0.73 \\
\hline $\begin{array}{l}\text { Ranstruct Reliability (CR) } \\
\text { Correlation (SqC) }\end{array}$ & \multicolumn{7}{|c|}{$0.038 \sim 0.489$} & \\
\hline
\end{tabular}

From Table 4, one can confidently argue that the research has its discriminant validity. The above analyses demonstrate that the construct validity of the research has been ensured.

\subsubsection{Reliability of the research}

From Table 4, one can see that the construct reliability of the research is well acceptable (Paswan, 2009), demonstrating the existence of internal consistency of the research. 
To further attest the reliability, Cronbach's alpha $(\alpha)$ and Spearman-Brown prophecy were also calculated in the analysis. Cronbach's alpha is a commonly used method (e.g., Wee and Quazi, 2005; $\mathrm{Wu}$, et al., 2004) to examine the reliability of survey questionnaire instrument, an $\alpha$ value of 0.7 or higher is an acceptable reliability (Wortzel, 1979; Santos, 1999); SpearmanBrown prophecy is also used by researchers as a supplementary method (e.g., Engs, 1996) for reliability test.

For this research, the Cronbach's $\alpha$ and the Spearman-Brown reliability coefficient are listed in Table 5, which further confirms that the survey investigation is reliable.

Table 5. Reliability test results

\begin{tabular}{|c|c|c|c|c|c|c|}
\hline Value $\quad$ Construct & DTA & FDA & DIP & MD & QD & QSW \\
\hline Cronbach's $\alpha$ & 0.81 & 0.72 & 0.70 & 0.71 & 0.76 & 0.71 \\
\hline Spearman-Brown prophecy & 0.94 & 0.80 & 0.85 & 0.92 & 0.82 & 0.85 \\
\hline
\end{tabular}

Thus based on the above conditions, one can claim that the research findings can be relied on to draw conclusions.

\section{Findings and analysis}

The e-retailers participating this research all have at least nation-wide business coverage, and are located in the areas with well developed logistics system infrastructure; the goods they are selling are all within the categories of those most often purchased by consumers (SJZTJ, 2015; CINIC, 2011); therefore, the consistency of the viewpoints from E-retailers in this research will only be examined based on their sizes.

\subsection{T-test on consistency of the viewpoints between different sized e-retailers}

Through T-test (Table 6), the authors have tested the consistency of the viewpoints on the importance/performance of the strategic elements among different sized e-retailers.

At $95 \%$ confidence level, the $\mathrm{p}$ values range from 0.07 to 0.98 (importance) and from 0.05 to 0.94 (performance) for the corresponding strategic elements; this demonstrates no significant difference between different sized e-retailers on these aspects. Thus the sample e-retailers can be treated as a whole for analysis of research findings.

Table 6, T-test comparison between different sized e-retailers (95\% confidence level)

\begin{tabular}{|l|l|l|}
\hline Strategic dimensions & P-value range for importance & P-value range for performance \\
\hline DTA & $0.15 \sim 0.65$ & $0.05 \sim 0.62$ \\
\hline FDA & $0.07 \sim 0.98$ & $0.13 \sim 0.67$ \\
\hline DIP & $0.24 \sim 0.88$ & $0.09 \sim 0.69$ \\
\hline MD & $0.18 \sim 0.64$ & $0.08 \sim 0.88$ \\
\hline QD & $0.07 \sim 0.67$ & $0.2 \sim 0.94$ \\
\hline QSW & $0.24 \sim 0.47$ & $0.51 \sim 0.54$ \\
\hline
\end{tabular}

4.2 The recognised importance/performance levels of the home delivery strategic elements The recognised importance level of the home delivery strategic elements and their performance level by the e-retailers are presented in Table 7 . 
Table 7. Strategic elements' importance and performance levels from the e-retailers (underlined items will be removed from the list due to their explicit low importance)

\begin{tabular}{|c|c|c|c|c|c|}
\hline Strategic & Importance & Performance & Strategic & Importance & Performance \\
\hline DTA_1 & 4.18 & 4.09 & DIP_5 & 3.36 & 3.45 \\
\hline DTA_2 & 3.64 & 4.27 & DIP_6 & 3.82 & 3.82 \\
\hline DTA_3 & 3.36 & 2.73 & DIP_7 & 3.91 & 3.82 \\
\hline DTA_4 & 4.00 & 3.45 & DIP_8 & 4.55 & 4.55 \\
\hline DTA 5 & $\underline{1.82}$ & $\underline{1.09}$ & DIP_9 & 4.00 & 3.27 \\
\hline FDA_1 & 4.00 & 4.64 & $\underline{\text { DIP10 }}$ & $\underline{2.45}$ & $\underline{2.18}$ \\
\hline FDA_2 & 3.45 & 3.09 & MD_1 & $\underline{2.89}$ & $\underline{2.96}$ \\
\hline FDA_3 & 3.55 & 3.73 & MD_2 & 4.00 & 4.00 \\
\hline FDA_4 & $\underline{1.91}$ & $\underline{1.27}$ & MD_3 & 3.55 & 3.36 \\
\hline FDA_5 & $\underline{1.82}$ & $\underline{1.64}$ & QD_1 & 4.82 & 4.55 \\
\hline FDA_6 & $\underline{1.91}$ & $\underline{1.36}$ & QD_2 & 4.55 & 4.09 \\
\hline DIP_1 & 4.91 & 5.00 & QD_3 & 4.55 & 3.73 \\
\hline DIP_2 & 4.73 & 4.64 & QSW_1 & 3.91 & 3.55 \\
\hline DIP_3 & 4.55 & 4.91 & QSW_2 & 3.91 & 3.36 \\
\hline DIP_4 & 4.45 & 4.45 & & & \\
\hline
\end{tabular}

filtering criterion, which was proposed by the focus group, one can see that: i) for Delivery time arrangement, except DTA_5, the rest of the strategic elements all have been recognised of their explicit importance to the home delivery performance by the sample Chinese e-retailers; ii) for Flexibility of the delivery arrangement, FDA_4, FDA_5, FDA_6 are not treated as explicitly important, while the rest are recognized as such; iii) for Delivery information provision, DIP_10 is not considered explicitly important, in contrary to the rest of the strategic elements in this dimension treated as explicitly important; iv) for Modes of delivery, MD_1 is not considered by e-retailers having explicit importance to the home delivery performance, while the others are treated as such; v) for Quality guarantee of delivery, all listed strategic elements under this dimension are regarded as explicitly important; vi) for Quality of the delivery staff's work, both proposed strategic elements are treated as explicitly important to ensure home delivery performance.

\subsection{Importance-performance analysis (IPA) and prioritisation of the strategic elements}

\subsubsection{IPA result}

To further understand the implementation status of the strategic elements by current Chinese eretailers in their home delivery process, as well as to prioritise the strategic elements to highlight the most critical ones for more effective and efficient home delivery action plan/strategy development, IPA analysis has been applied. The IPA result is depicted in Figure 2. In Figure 2, excluding those removed elements regarded as not explicitly important (with importance scores of 3 and below), the rest of the elements are clustered into four quadrants using their average importance rating (4.08) and average performance rating (3.94) as the coordinate axes. 


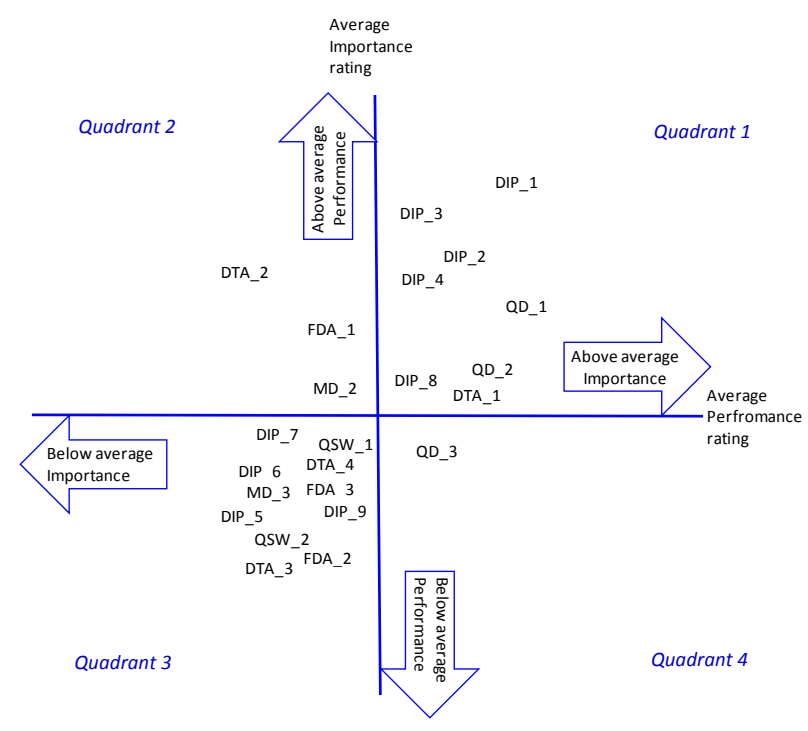

Figure 2. IPA result depicting importance/performance for prioritising the strategic elements

The clustered strategic elements in the four quadrants are:

Quadrant 1 - Strategic elements with high importance level and high performance level: DIP_1, DIP_2, DIP_3, DIP_4, DIP_8, QD_1, QD_2 and DTA_1.

Quadrant 2 - Strategic elements with low importance level and high performance level: DTA_2, FDA_1 and MD_2.

Quadrant 3 - Strategic elements with low importance level and low performance level: DIP_5, DIP_6, DIP_7, DIP_9, FDA_2, FDA_3, MD_3, DTA_3, DTA_4, QSW_1 and QSW_2.

Quadrant 4 - Strategic elements with high importance level and low performance level: only QD_3.

\subsubsection{Prioritisation of the strategic elements}

Consequentially, the above four quadrant elements can be further categorised into three critical strategic element groups (CSEGs) to prioritise their importance:

Critical strategic element group 1 - CSEG1, includes the elements with high importance level and low performance level, herein refers to Quadrant 4 elements, which only has QD_3; for CSEG1 element, an e-retailer must devote largest effort and resources to ensure its full implementation and success in order to ensure the healthy survival of the business and to achieve higher level of competitiveness.

Critical strategic element group 2 - CSEG2, includes the elements with high importance level and high performance level and those with low importance level and low performance level, herein refers to Quadrants 1 and 3 elements; for CSEG2 elements, an e-retailer needs to devote moderate however continuous effort and resources to maintain/improve those strategic elements' implementation to ensure a consistent business performance.

Critical strategic element group 3 - CSEG3, includes the elements with low importance level and high performance level, herein refers to Quadrant 2 elements; for CSEG3 elements, in a short term, an e-retailer does not need to input further effort and resources for these strategic elements' implementation, but a regular check should be in process to avoid performance decrease.

The following Table 8 summarises the finalised critical strategic elements for e-retailers' home delivery operations, arranged under their corresponding CSEGs. 
Table 8. CSEGs and their corresponding elements

\begin{tabular}{|l||l|l|}
\hline CSEGs & Critical strategic elements \\
\hline CSEG1 & QD_3 & Quick action to customers' complaint, increase the satisfaction level of customers \\
\hline CSEG2 & DIP_1, & Clearly links to the delivery information website on the retailers' homepage; \\
& DIP_2, & Customer can easily find delivery information on the website through input key words; \\
& DIP_3 & Information of payments clearly stated; \\
& DIP_4, & Customer can track the delivery status information on the ordered goods; \\
& DIP_8, & Customer signature after receiving the goods; \\
& QD_1, & Avoiding the damage of goods through using materials with sufficient strength; \\
& QD_2, & Training delivery staff avoiding the knock and scratch; \\
& DTA_1, & Same day delivery; \\
& MD_3 & Combination of retailer delivery and third party logistics provider delivery; \\
& DIP_5, & Retailer informs customers of the delivery status information instantly through message/email; \\
& DIP_6, & Instantly reply email/message, etc. from customers' enquiry on the delivery status of goods; \\
& DIP_7, & Instantly reply customers' telephone enquiry of the delivery status of goods; \\
& DIP_9, & On website, clearly stating the request of signature for customer after receipt of goods; \\
& FDA_2, & Can deliver according to the customer's special requirements; \\
& FDA_3, & Can deliver to the different location decided by customers; \\
& DTA_3, & Weekend delivery; \\
& DTA_4, & Delivery by customer appointed date; \\
& QSW_1, & Recruiting high quality staff; \\
& QSW_2 & Regular training before and after the staff assuming posts \\
\hline
\end{tabular}

\subsection{Test application of the CSEGs}

To examine the findings' applicability, five e-retailers have test applied the CSEGs in guiding their home delivery strategic action plans' development and implementation, following the CSEGs' prioritization order.

The assessment of the applicability focused on three aspects: relevancy, effectiveness and efficiency of the CSEGs to/in facilitating the e-retailers' home delivery strategy development and implementation. Relevancy, effectiveness and efficiency have been applied in other research for evaluating a model/framework's applicability (e.g., Wang, et al. 2005).

Table 9 summarises the average assessment ratings from the five e-retailers after one year's test application.

Table 9. Average assessment ratings on CSEGs' applicability

\begin{tabular}{|l|c|}
\hline \multicolumn{1}{|c|}{ Assessment dimension } & Average rating \\
\hline $\begin{array}{l}\text { Relevancy of the CSEGs to the e-retailers' home delivery strategy development and } \\
\text { implementation (scale: from 1 - Very irrelevant to 5 - Very relevant) }\end{array}$ & 4.8 \\
\hline $\begin{array}{l}\text { Effectiveness of the CSEGs in facilitating the e-retailers' home delivery strategy development } \\
\text { and implementation (scale: from 1 - Very ineffective to 5 - Very effective) }\end{array}$ & 4.6 \\
\hline $\begin{array}{l}\text { Efficiency of the CSEGs in facilitating the e-retailers' home delivery strategy development } \\
\text { and implementation (scale: from 1 - Very inefficient to 5 - Very efficient) }\end{array}$ & 4.2 \\
\hline
\end{tabular}

As demonstrated in Table 9, the application results are all positive, which endorse the CSEGs and their elements' applicability. 


\section{Conclusions, implications, limitations and future research}

\subsection{Conclusions}

With the fast development of the online retailing, home delivery is becoming more crucial for e-retailers to ensure the customers' satisfaction on their service and to maintain their businesses' healthy survival under the intensified competition.

As summarised in Table 8 and Figure 2, this research has explored, identified and prioritised into critical strategic element groups (CSEGs) the most important strategic elements currently adopted and implemented by Chinese e-retailers in their home delivery operations; these strategic elements have been classified into three CSEGs and prioritised as CSEG1, CSEG2 and CSEG3. CSEG1 includes only one strategic element: QD_3; CSEG2 includes the strategic elements of DIP_1, DIP_2, DIP_3, DIP_4, DIP_8, QD_1, QD_2, DTA_1, MD_3, DIP_5, DIP_6, DIP_7, DIP_9, FDA_2, FDA_3, DTA_3, DTA_4, QSW_1, QSW_2; CSEG3 includes the strategic elements of DTA_2, FDA_1, MD_2. E-retailers can apply the relevant strategic elements within the three CSEGS and follow their prioritisation to allocate appropriate level of resources and effort accordingly, to maintain a high level of customer service and meet customer demand in Chinese e-retailing marketplace, as well as in other emerging marketplaces; since as contended by Chang, et al. (2013), these marketplaces share the similar development attributes as China's.

Meanwhile, the research findings have demonstrated that the majority of e-retailing home delivery strategic elements applied by the e-retailers in developed countries are also seen as explicitly important in implementation in the developing marketplace. Namely majority of the strategic elements have a wider applicability.

As evidenced by the test application of the three CSEGS and their content strategic elements, the e-retailers can follow the prioritisation of the strategic elements to plan and allocate resources and effort for improving the corresponding business aspects' performance, to enhance and ensure a satisfactory home delivery service to customers, and to enhance their competitiveness in marketplace.

The findings have also revealed that some strategic elements for ensuring home delivery's efficacy implemented in developed countries are not treated as important by Chinese eretailers. This phenomenon needs to be borne in mind when international e-retailers develop strategies for entering or operating in Chinese and other developing marketplaces.

\subsection{Implications}

The research findings guide/inform the strategy development and implementation for eretailers entering and/or operating in Chinese marketplace, meanwhile contribute positively to the theoretical knowledge pool of e-retailers' logistics performance improvement.

An additional contribution of the research is that the findings can also be referential to the eretail strategy development for entering and operating in other emerging markets similar to China's. This point is particularly meaningful for those e-retailers that want to expand the outreaching and increase the popularity of their businesses in the global marketplace.

\subsection{Limitations}


Due to the relatively small sample size and the way of sample selection, there is a possibility that the findings are not exhaustive; and the research would benefit from a larger sample. Thus the authors do not claim the findings provide all-inclusive insights. Meanwhile the research focuses on China, albeit researchers have claimed that China and other emerging markets share similarity in e-retail industry development, the CSEGs when applied in other countries might need some adaptation. Nevertheless, as an empirical and exploratory oriented research, the findings are effective to guide the real world e-retailers' home delivery strategy development and performance improvement.

\subsection{Future research}

Future research can be conducted to focus on:

- The reasons for some international e-retailers' unsuccessful experience under the backcloth that many strategies applied by e-retailers in developed countries also have been regarded as important in implementation by their counterparts in China;

- A comparative study of the application levels of the individual strategic elements between foreign and Chinese e-retailers and the underlying reasons for the similarity and difference;

- The research focused on the online only retailers (pure players), a future research comparing the similarity and difference of home delivery strategies between pure players and multichannel ones from China and other countries will provide more insights;

- A further comparative investigation on the viewpoints between customers and e-retailers on the importance level of the identified strategic elements will shed more light into the field.

\section{Reference}

Abdul-Muhmin, A. G. (2010), Repeat Purchase Intentions in Online Shopping: The Role of Satisfaction, Attitude, and Online Retailers' Performance, Journal of International Consumer Marketing, Vol. 23, No. 1, pp. 5-20.

Asdemir, K., Jacob, V. S. and Krishnan, R. (2009), Dynamic pricing of multiple home delivery options, European Journal of Operational Research, Vol. 196, pp. 246-257.

Benady, D. (2013), Dynamic delivery: changing the rules of retail, Marketing, retrieved at [Accessed December]: http://www.marketingmagazine.co.uk/article/1208897/dynamicdelivery-changing-rules-retail.

Briggs, E., Landry, T. D. and Daugherty, P. J. (2010), Investigating the influence of velocity performance on satisfaction with third party logistics service, Industrial Marketing Management, Vol. 39, pp. 640-649.

Bruer, S. (2008), Internet Retailing Opportunities and Challenges for the UK's Distribution Property Markets, [Accessed January 2013]: http://www.prologis.co.uk/pdfs/e-tail.pdf.

China E-commerce Research Centre (CERC) (2012), The monitoring report on the experience and complaints of the Chinese e-commerce users in 2011, online at [Accessed January 2013]: http://www.100ec.cn.

China E-commerce Research Centre (CERC) (2014), Monitoring report on the e-commerce market data of China in 2013, online at [Accessed April]: http://www.100ec.cn.

Clark E. (2011), China E-Commerce Seen Spiking, Women's Wear Daily, Vol. 202, No. 108. CMIC (2012), Balance regional development, build up e-commerce with local characteristics. Chang, E., Chen, Y. and Dobbs, R. (2013), China's e-tail revolution, McKinsey Quarterly, No. 3. 
China Market Intelligence Centre, online at [Accessed August]: http://www.ccidreport.com/ market/article/content/3698/ 201207/ 277364.html.

CINIC (2011), "Research report of Chinese BtC direct goods online shoppers", China Internet Network Information Center, on-line at [Accessed May]: https://www.cnnic.net.cn/hlwfzyj/ hlwxzbg/201106/P020120709345285004076.pdf.

Cole, D. A. (1987), Utility of confirmatory factor analysis in test validation research, Journal of Consulting and Clinical Psychology, Vol. 55, No. 4, pp. 584-594.

comScore (2012), Online Shopping Customer Experience Study, comScore, Inc., on line at [Accessed December 2013]: http://www.pressroom.ups.com/pressroom/staticfiles/pdf/fact_ sheets/comScore_Customer_Experience_White_Paper.pdf

Costello, A. B. and Osborne, J. W. (2005), Best practices in exploratory factor analysis: Four recommendations for getting the most from your analysis, Practical Assessment Research \& Evaluation, Vol. 10, No. 7, July 2005.

Cronbach, L. J. and Meehl, P. E. (1955), CONSTRUCT VALIDITY IN PSYCHOLOGICAL TESTS, Psychological Bulletin, Vol. 52, pp. 281-302.

Crowley, G. H. and Gilreath, C. L. (2002) "Probing user perceptions of service quality: using focus groups to enhance quantitative survey", Performance Measurement and Metrics, Vol. 3, No. 2, pp. 78-84.

CYONE (2013), Listing the famous foreign multinational companies recently withdrawing from China, on line at [Accessed April 2014]: www.cyone.com.cn/Article/Aritcle_23333.html. de Koster, R. B. M. (2003), Distribution Strategies for Online Retailers, IEEE TRANSACTIONS ON ENGINEERING MANAGEMENT, Vol. 50, No. 4, pp. 448-457.

DMOZlist (2012), Computer Network - E-commerce, online at: [Accessed August] http://www.chinadmoz.org.

EEO (2010), Gradual imbalance of the distribution of e-commerce, three major factors impeding its development, The Economic Observer, online at: [Accessed August 2012] http://www.eeo.com.cn/2010/1009/ 182242.shtml.

Engs, R. C. (1996), Construct validity and re-assessment of the reliability of the HEALTH CONCERN QUESTIONNAIRE, Advances in Health Education/Current Research (4), Edited by Robert H.L. Feldman and James H. Humphrey, AMS, Press, Inc., New York: pp. 303-313.

European Commission (2005), The new SME definition User guide and model declaration, online at [Accessed November 2013]: ENTERPRISE ANDINDUSTRY PUBLICATIONS, http://ec.europa.eu/enterprise/policies/sme/files/sme_definition/sme_user_guide_en.pdf.

Evason, E. and Whittington, D. (1997), Patients' perceptions of quality in a Northern Ireland hospital trust: a focus group study, International Journal of Health Care Quality Assurance, Vol. 10, No. 1, pp. 7-19.

Forbes, L. P. Kelley, S. W. and Hoffman, K. D. (2005), Typologies of e-commerce retail failures and recovery strategies, Journal of Services Marketing, Vol. 19, No. 5, pp. 280-292.

Galpin, P. (2013), The importance of high delivery standards, online at [Accessed December]: http://www.smallbusiness.co.uk/running-a-business/business-management/2142983/theimportance-of-high-delivery-standards.thtml.

Ganesan, S., Gorge, M., Jap, S., Palmatier, R. W. and Weitz, B. (2009), Supply Chain Management and Retailer Performance: Emerging Trends, Issues, and Implications for Research and Practice, Journal of Retailing, Vol. 85, No. 1, pp. 84-94.

Gil-Saura, I., Servera-Francés, D. and Fuentes-Blasco, M. (2010), Antecedents and consequences of logistics value: And empirical investigation in the Spanish market, Industrial Marketing Management, Vol. 39, pp. 493-506. 
Goethals, F., Leclercq-Vandelannoitte, A., Tütüncü, Y. (2011), French consumers' perceptions of the unattended delivery model for e-grocery retailing, Journal of Retailing and Consumer Services, Vol. 19, pp. 133-139.

Gooderham, E. (2011), UK internet e-tailers need to wake up to the market opportunity of international business, online at [Accessed January 2013]: http://www.internationaltrade. co.uk/content.php?CID $=1$.

Greasley, A. and Assi, A. (2012), Improving "last mile" delivery performance to retailers in hub and spoke distribution systems, Journal of Manufacturing Technology Management, Vol. 23, No. 6, pp. 794-805.

Grewal, D. and Levy, M. (2009), Emerging Issues in Retailing Research, Journal of Retailing, Vol. 85, No. 4, pp. 522-526.

JLL (2013), E-commerce boom triggers transformation in retail logistics Driving a global wave of demand for new logistics facilities, Global e-commerce and retail logistics, online at [Accessed April 2014]: www.jll'com/Research/eCommerce_boom_triggers_transformation_ in_retail_logistics_whitepaper_Nov2013.pdf.

Jopson, B. (2013), Retailers home in on the perfect delivery, online at [Accessed January 2014]: http://www.ft.com/cms/s/0/1ce9b684-5e99-11e3-8621-00144feabdc0.html\#axzz2qm UnCNLg.

Kaffash, J. (2012), Failed first time deliveries expected to cost etailers $£ 851 \mathrm{~m}$ this year, online at [Accessed January 2013]: http://www.retail-week.com/multichannel/online-retail/failedfirst-time-deliveries-expected-to-cost-etailers-851m-this-year/5041394.article.

Karakaya, F. (2001), Electronic Commerce: Current and Future Practices, Managerial Finance, Vol. 27, No. 7, pp. 42-53.

Kimberlin, C. L. and Winterstein, A. G. (2008), "Validity and reliability of measurement instruments used in research", Am J Health-Syst Pharm, Vol. 65, Dec. 1, pp. 2276-2284.

Krueger, R.A. (1994), Focus Groups: A Practical Guide for Applied Research, Sage, Thousand Oaks, CA.

Kuhn, H. and Sternbeck, M. G. (2013), Integrative retail logistics: An exploratory study, Oper Manag Res, Vol. 6, pp. 2-18.

Lee, H. L. and Whang, S. (2001), Winning the Last Mile of e-Commerce, Sloan Management Review, Vol. 42, No. 4, pp. 54-62.

Li, H. and Dinlersoz, E. (2012), Quality-based Price Discrimination: Evidence from Internet Retailers' Shipping Options, Journal of Retailing, Vol. 88, No. 2, pp. 276-290.

Likert, R. (1932), A Technique for the Measurement of Attitudes, Archives of Psychology: New York.

Liao, S., Chen, Y. and Lin, Y. (2011), Mining customer knowledge to implement online shopping and home delivery for hypermarkets, Expert Systems with Applications, Vol. 38, No. 4, pp. 3982-3991.

Liu, J. and Xu, W. (2010), Nearly 1000 internet retailers went out of marketplace, soft environment needs to be improved, on line at [Accessed April 2014]: http://tech.qq.com/a/ 20101231/000250.htm.

Liu, N. (2012), The foreign invested e-tailers meet difficulty to adapt to local environment, Newegg might follow the same fate of Rakutien", on line at [Accessed April 2014]: www.techweb.com.cn/internet/2012-07-09/1211843.shtml.

Lockwood, L. (2013), China Tops E-Commerce Opportunity Study, Women's Wear Daily, Vol. 206, No. 104. 
MacCallum, R. C., Widaman, K. F., Zhang, S. and Hong S. (1999), Sample size in factor analysis. Psychological Methods, Vol. 4, pp. 84-99.

Martilla, J. and James J. (1977), Importance - Performance Analysis, Journal of Marketing, Vol. 14, pp. 77-79.

MICROS (2012), online retail delivery Report 2012, online at [Accessed January 2013]: http://www.metapack.com/sites/default/files/downloads/whitepaper/2012-Online-Retail-

Delivery-Report-IMRG-Annex-sponsored-by-MetaPack.pdf.

Park, M. and Regan, A. (2004), ISSUES IN EMERGING HOME DELIVERY OPERATIONS, Research Paper, University of California Transportation Center: Los Angeles, CA.

Pastor, D. A. (2013), Validity: Factor Analysis, online at [Accessed September]: www.jmu.edu/outreach/wm_library/Validity_Factor_Analysis.pptx.

Paswan, A. (2009), Confirmatory Factor Analysis and Structural Equations Modeling: An Introduction, online at [Accessed Feburary, 2013]: www.cob.unt.edu/slides/paswan/ BUSI6280/CFA-SEM\%20-\%20Intro-May\%2018\%202009.pp

Preacher, K. J. and MacCallum, R. C. (2002), Exploratory Factor Analysis in Behavior Genetics Research: Factor Recovery with Small Sample Sizes, Behavior Genetics, Vol. 32, pp. 153-161.

Punakivi, M., Yrjölä, H. and Holmström, J. (2001), Solving the last mile issue: reception box or delivery box? International Journal of Physical Distribution and Logistics Management, Vol. 31, No. 6, pp. 427-439.

Punakivi, M. and Saranen, J. (2001), Identifying the success factors in e-grocery home delivery, International Journal of Retail \& Distribution Management, Vol. 29, No. 4, pp. 156163.

Rao, S., Goldsby, T. J., Griffis, S. E. and Iyengar, D. (2011), Electronic Logistics Service Quality (e-LSQ): Its Impact on the Customer's Purchase Satsfaction and Retention, Journal of Business Logistics, Vol. 32, No. 2, pp. 167-179.

Rosea, S., Clarka, M., Samouel, P. and Hair, N. (2012), Online Customer Experience in eRetailing: An empirical model of Antecedents and Outcomes, Journal of Retailing, Vol. 88, No. 2, pp. 308-322.

Rutter, J. and Southerton, D. (2000), E-shopping: delivering the goods? Consumer Policy Review, Vol. 10, No. 4, pp.139-144.

Sadi, M. A. and Iftikhar, Q. (2011), Factors critical to the success of small-medium sized business marketing: A view from the tourism industry in Saudi Arabia, African Journal of Marketing Management Vol. 3, No. 9, pp. 226-232.

Santos, J. R. A. (1999), Cronbach's Alpha: A Tool for Assessing the Reliability of Scales, Journal of Extension, Vol. 37, No.2, pp. 1-5.

Sebastianelli, R. and Tamimi, N. (2013), An Examination of Attributes Affecting Consumers' Perceptions of E-tailer Quality, Journal of Internet Commerce, Vol. 12, No. 3, pp. 268-283.

SJZTJ (2015), The investigation report of the residents' on-line shopping in Shijiazhuang city, Shijiazhuang statistics bureau, Shijiazhuang statistical information intranet, online at[Accessed May]: http://www.sjztj.gov.cn/index.php?m=content\&c=index\&a=show\&catid=67\&id=515.

Spijkerman, R. P. (2008), Appreciation of apparel e-tailing by Dutch fashion consumers, Journal of fashion Marketing and Management, Vol. 12, No. 1, pp. 119-137.

Starkey (2010), e-Retail - Using home delivery as a service differentiator and strategic marketing tool, Journal of Direct, Data and Digital Marketing Practice, Vol. 12, No. 2. pp. 165173. 
Statwiki (2012), Exploratory Factor Analysis, online at [Accessed December]: http://statwiki. kolobkreations.com/wiki/Exploratory_Factor_Analysis.

Stokes, A. and Jensen, T. D. (2011), CO-BRANDING: THE EFFECTS OF E-RETAILER AND DELIVERY CARRIER FAMILIARITY ON PRICE AND E-TAILER PERCEPTIONS, Journal of Marketing Theory and Practice, Vol. 19, No. 1, pp. 97-108.

Teller, C., Kotzab, H. and Grant, D. B. (2006), The consumer direct services revolution in grocery retailing: an exploratory investigation, Managing Service Quality, Vol. 16, No. 1, pp. 78-96.

The Centre for Retail Research (2012), Online Retailing: Britain and Europe 2012, online at [Accessed January 2013]: http://www.retailresearch.org/onlineretailing.php.

TopCapital (2013), The wave of e-retailers' bankruptcy comes? "end of the world" also the "Noah's Arc", online at [Accessed April 2014]: http://www.topcapital.com.cn/pages/ reportdata.asp?id $=5360$.

van Beuningen, J. (2012), The Satisfaction With Life Scale Examining Construct Validity, Statistics Netherlands, The Hague/Heerlen.

Wang, C., Luxhøj, J. T. and Johansen, J. (2005), “Applying a Manufacturing Vision (MV) Development Prototype in Practice”, Production Planning \& Control, Vol. 16, No. 3, pp. 273 285.

Wang, C., Yang, T., Mao, Z., Zhang, L., Vaughan, J. and Mercer, J. (2011-12), An Empirical Exploration of Hospital Service Quality Assessment Criteria in China, Journal of General Management, Vol. 37, No. 2, pp. 51-68.

Wang, X. and Ren, Z. J. (2012), How to Compete in China's E-Commerce Market, MIT Sloan Management Review, Vol. 54, No. 1, pages 7.

Wee, Y. S. and Quazi, H. A. (2005), Development and validation of critical factors of environmental management, Industrial Management and Data Systems, Vol. 105, No. 1/2, pp. 96, 19 pgs.

Westen, D. and Rosenthal, R. (2003), Quantifying construct validity: Two simple measures. Journal of Personality and Social Psychology, Vol. 84, No. 3, pp. 608-618.

Wortzel, R., (1979), New life style determinants of women's food shopping behaviour, Journal of Marketing, Vol. 43, pp. 28-29.

Wu, W.-Y., Chiang C.-Y., Wu Y.-J. and Tu H.-J. (2004), The influencing factors of commitment and business integration on supply chain management, Industrial Management and Data Systems, Vol. 104, No. 4, pp. 322-333.

51ZJXM (2011a), Top 100 Net Enterprises in China 2011, Tengxun is on the top in revenue, online at: [Accessed July 2012] http://news.51zjxm.com/bangdan/20120704/17733.html.

51ZJXM (2011b), Ranking list of Chinese E-commerce Enterprises in 2011, online at: [Accessed June] http://news.51zjxm.com/bangdan/20120605/17734.html.

Zhang, L. and Zhang, Y. (2012), A Comparative Study of Environmental Impact of Two Delivery Systems in the Business-to-Customer Book Retail Sector, Journal of Industrial Ecology, Vol. 17, No. 3, pp. 407-417.

Yu, C. H. (2012), Reliability and Validity, online at: [Accessed August, 2013] http://www. creative-wisdom.com/teaching/assessment/reliability.html. 